\title{
Expert System Of Nose Disease With Hybrid Method
}

\author{
Yogi Wiyandra*1, Firna Yenila ${ }^{2}$ \\ Department Of Computer System, University Of Putra Indonesia YPTK Padang*1 \\ Department Of Information System, University Of Putra Indonesia YPTK Padang ${ }^{2}$ \\ E-mail : yogiwiyandra@upiyptk.ac.id*1, firnayenila@upiytk.ac.id ${ }^{2}$ \\ *Corresponding author
}

\begin{abstract}
Nasal disease is a type of disease that is classified as often afflicting someone. And it is not uncommon among people to conduct a direct examination on ENT specialists to find out the type of disease they are experiencing. Thus an alternative is needed to find out early the problems that arise from the nose. The intended alternative is to build a system in the form of an expert system that uses one's expertise in providing knowledge in the form of a nose condition. The system was built using a hybrid method that combines the forward chaining method and the certainty factor. So, the results or knowledge given to the public is confirmed by the percentage given.
\end{abstract}

Keywords -nasal disease, expert system, hybrid methode

\section{INTRODUCTION}

The nose is an open cavity through which air is flowed into the lungs [1]. The nose is the initial part of the breathing process, in the nose there is a mucosa that functions to moisturize so that the air entering the lungs does not become dry [2]. If the air that enters the lungs is dry then this will adversely affect the human respiratory system. As a human respiration nose is the most important thing and is very susceptible to bacteria and even viruses that spread through the air, unfortunately many people do not care about nasal health due to air pollution that they breathe every day and cause nasal disease[10].

Diseases of the ear, nose, ear (ENT) itself has many kinds with a variety of symptoms caused. Many ENT diseases are caused by bacterial and viral infections that attack certain parts of the organ [8].

Treatment of infections is still a major problem in the health sector. The incidence of tonsillitis in Indonesia is around $23 \%$. With so many kinds of diseases and symptoms that are almost the same, it makes it difficult for doctors to diagnose and comparison of the population in Indonesia with limited doctors makes people have to queuelong time to go to the local hospital institution [4]

Generally, to find out someone suffering from the relevant nasal disease should consult a general practitioner or even an ENT specialist, but this provides new obstacles for patients as previously explained [6]. One solution provided to overcome this is to build an expert system. Expert system is a system in the form of computer software where the computer is made as if thinking like an expert / expert in its field [3].

The facts used are the symptoms felt by the patient, while the conclusion is the result of diagnosing the disease. This expert system is expected to help the public to find out about the nose disease that is being suffered without having to go to a doctor first, patients simply enter the symptoms of the disease being felt to then be processed by a computer and display the diagnosis results. Conclusions from the system are made using a hybrid method that combines 
forward chaining with certainty factors. The certainty factor method provides confirmation of the results given by the expert in consultation with the system.

\section{RESEARCH METHOD AND LITERATUR REVIEW}

\subsection{Research method}

The research was clearly planned through several aspects as follows:

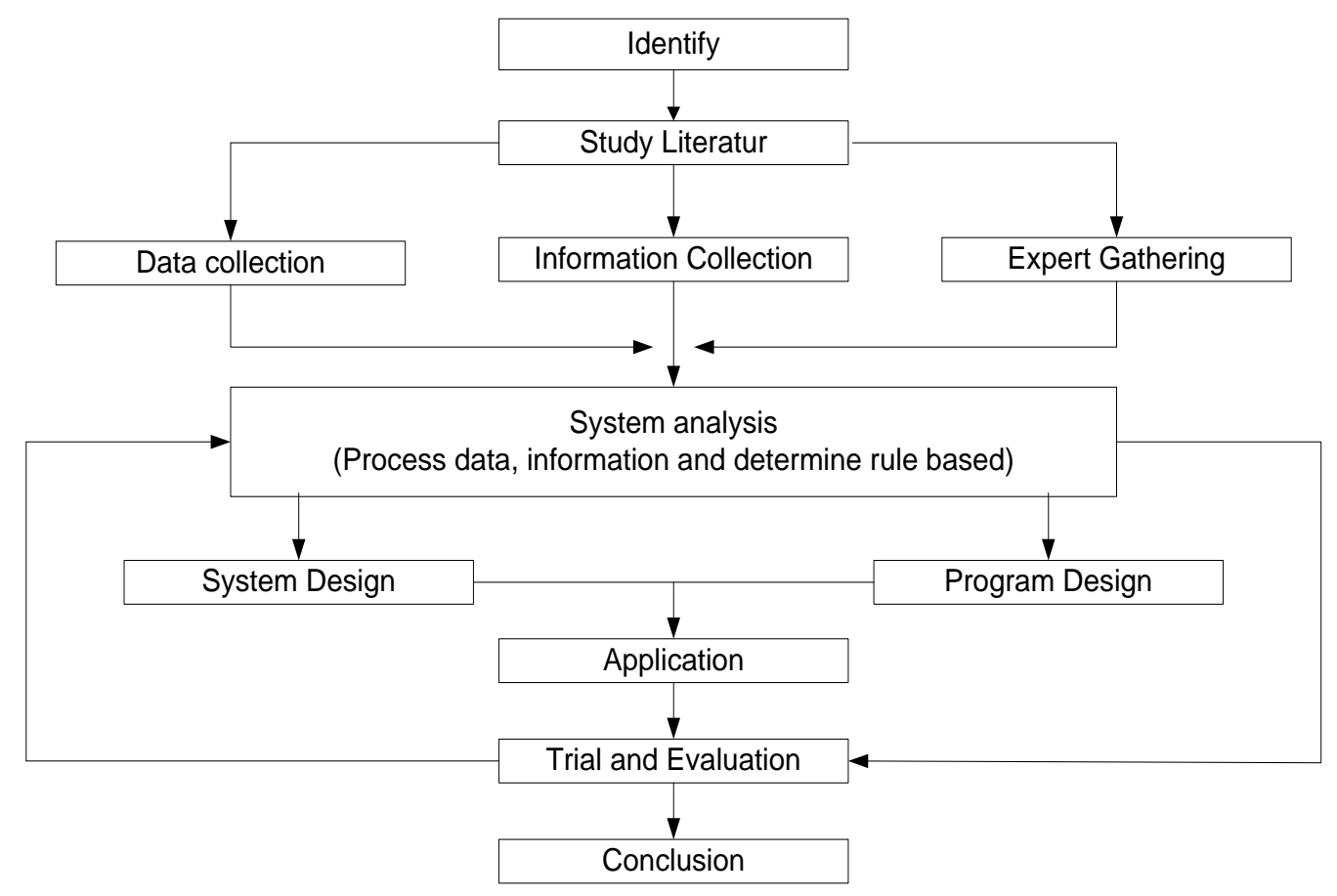

Figure 1.Methodolgy Research

\subsection{Literatur Review}

The expert system was allegedly one of the programs that made it easy for an expert to describe the results of expert thinking into computers. This expert system is one of the media used to consult directly between system users and experts without waiting time or queuing [5].

\subsection{Hybdrid Method}

This system was created using a hybrid method that combines forward chaining with certainty factors.

a. Forward Chaining

The process of forward chaining will begin by providing activities that are being experienced by the patient, then the condition is processed through the rules of the process of determining solutions or conclusions until an output is obtained [9].

b. Certainty Factor 
In the process of searching for the tracking tree above to determine the status of the diagnosis it will be calculated by the proportion formula which is to determine the likelihood of relative frequency [7]

The proportion formula in the expert system for diagnosing nose disease is:

Information :

P : : Proportion

$\mathrm{n}(\mathrm{A}) \quad$ : Many symptoms are detected in disease A.

$\mathrm{n}(\mathrm{S}) \quad$ : Many symptoms that have A. Disease

$$
\mathrm{p}=\frac{n(A)}{n(S)} \times 100 \%
$$

After knowing the proportional value, the status of the diagnosis result will be determined by the following rules:

1. Proportion Value $=(100 \%)$, the status of the diagnosis results is "Certain".

2. Proportion Value $=(>=56 \%$ AND $<100 \%)$ then the status of the diagnosis result is "Possible".

3. Proportion Value $=(<56 \%)$ then the status of diagnosis results is "Doubtful".

\section{RESULTS AND DISCUSSION}

From the results of collecting data, information and knowledge from experts at the time of observation, we obtained several tables which will be described in this section according to the problem or cause of nuse disease.

Table 2. The Symtoms Of Nuse disease

\begin{tabular}{|l|l|}
\hline No & \\
\hline G001 & Nasal congestion \\
\hline G002 & Sneezing \\
\hline G003 & Watery snot \\
\hline G004 & Headache \\
\hline G005 & Ear pain \\
\hline G006 & Buzzing ears \\
\hline G007 & Itchy eyes \\
\hline G008 & Smell less \\
\hline G009 & Wet nose \\
\hline G010 & Smelly nose \\
\hline G011 & Nasal pain \\
\hline G012 & Difficulty breathing \\
\hline G013 & Nasal voice \\
\hline G014 & Neck pain \\
\hline G015 & Itchy nose (nasal irritation) \\
\hline G016 & Runny nose mixed with snot \\
\hline G017 & Difficult to blow your nose \\
\hline G018 & Itchy throat \\
\hline G019 & Pain in the face \\
\hline G020 & Cough \\
\hline
\end{tabular}


Journal of Applied Intelligent System (e-ISSN : 2502-9401 | p-ISSN : 2503-0493)

Vol. 4 No. 2, December 2019, pp. $67-74$

\begin{tabular}{|l|l|}
\hline G021 & Snore \\
\hline G022 & Mucus in the throat \\
\hline G023 & Muscle ache \\
\hline G024 & Limp \\
\hline G025 & Diarrhea \\
\hline G026 & Fever \\
\hline
\end{tabular}

Table 2. Type of Nose Disease

\begin{tabular}{|c|l|}
\hline No & \multicolumn{1}{|c|}{ The Symtoms } \\
\hline P001 & Nasal congestion \\
\hline P002 & Sneezing \\
\hline P003 & Watery snot \\
\hline P004 & Headache \\
\hline P005 & Ear pain \\
\hline
\end{tabular}

Table 3. Weight of Certainty Factor

\begin{tabular}{|c|l|c|}
\hline No & \multicolumn{1}{|c|}{ The Symtoms } & User Value \\
\hline 1 & No & 0 \\
\hline 2 & Do not know & 0,2 \\
\hline 3 & A little sure & 0,4 \\
\hline 4 & Pretty sure & 0,6 \\
\hline 5 & Sure & 0,8 \\
\hline 6 & Very confident & 1 \\
\hline
\end{tabular}

Table 4. Value Of certainty Factor for each premise

\begin{tabular}{|c|c|c|}
\hline No & The Symtoms & Value \\
\hline G001 & Nasal congestion & 0.2 \\
\hline G002 & Sneezing & 0.4 \\
\hline G003 & Watery snot & 0.4 \\
\hline G004 & Headache & 0.6 \\
\hline G005 & Ear pain & 0.7 \\
\hline G006 & Buzzing ears & 0.4 \\
\hline G007 & Itchy eyes & 0.6 \\
\hline G008 & Smell less & 0.8 \\
\hline G009 & Wet nose & 0.8 \\
\hline G010 & Smelly nose & 0.9 \\
\hline G011 & Nasal pain & 0.5 \\
\hline G012 & Difficulty breathing & 0.8 \\
\hline G013 & Nasal voice & 0.2 \\
\hline G014 & Neck pain & 0.5 \\
\hline G015 & Itchy nose (nasal irritation) & 0.7 \\
\hline G016 & Runny nose mixed with snot & 0.8 \\
\hline G017 & Difficult to blow your nose & 0.5 \\
\hline G018 & Itchy throat & 0.2 \\
\hline G019 & Pain in the face & 0.1 \\
\hline G020 & Cough & 0.3 \\
\hline G021 & Snore & 0.5 \\
\hline G022 & Mucus in the throat & 0.5 \\
\hline G023 & Muscle ache & 0.3 \\
\hline G024 & Limp & 0.5 \\
\hline G025 & Diarrhea & 0.3 \\
\hline
\end{tabular}


Journal of Applied Intelligent System (e-ISSN : 2502-9401 | p-ISSN : 2503-0493)

Vol. 4 No. 2, December 2019, pp. $67-74$

\begin{tabular}{|l|l|l|}
\hline G026 & Fever & 0.5 \\
\hline
\end{tabular}

From some of the tables above, a decision tree is needed to determine the rules used in producing decisions like the following figure:

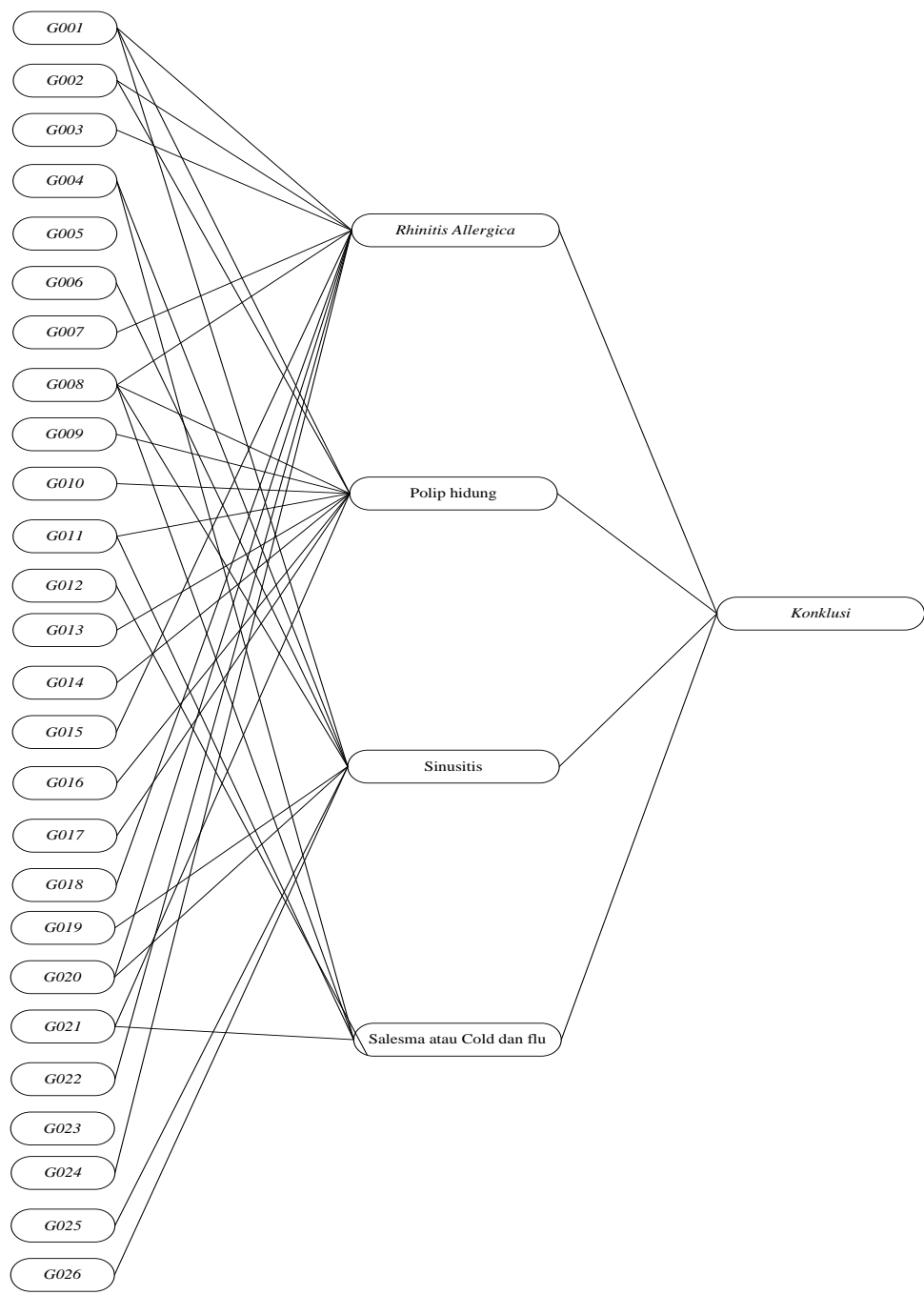

Figure 1.Decision Tree

The first, when we use of the system, the user will be presented with the following layout which aims to provide preliminary information to the patient regarding nose disease.

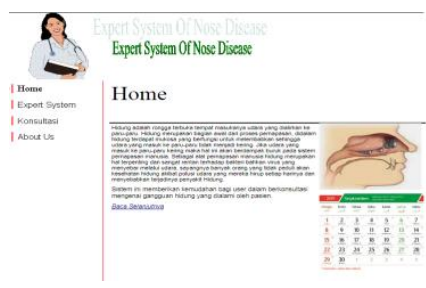

Figure 2.Home 
After the user does the initial stage, go directly to the following layout which provides information about the expert system.

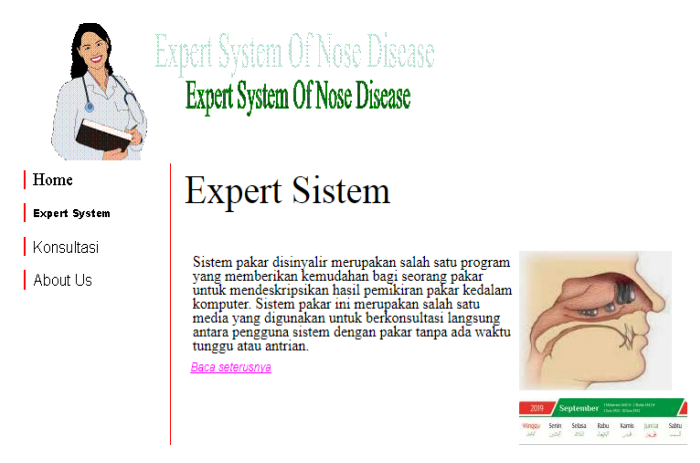

Figure 3.Expert System

The display provides information to experts to understand the expert system in general. Then the user will be directed to the consultation tools. Here the user is asked to answer every question raised in accordance with the actual conditions, and the user is also asked to confirm the answer to that question by providing a certainty of percentage experienced by the user as shown below:

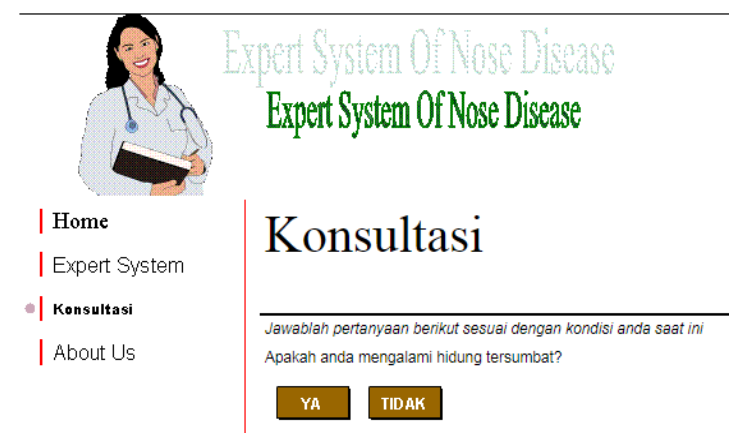

Figure 4.Consultation

From this question, if the user answers YES then the system will direct the user to the following conditions:

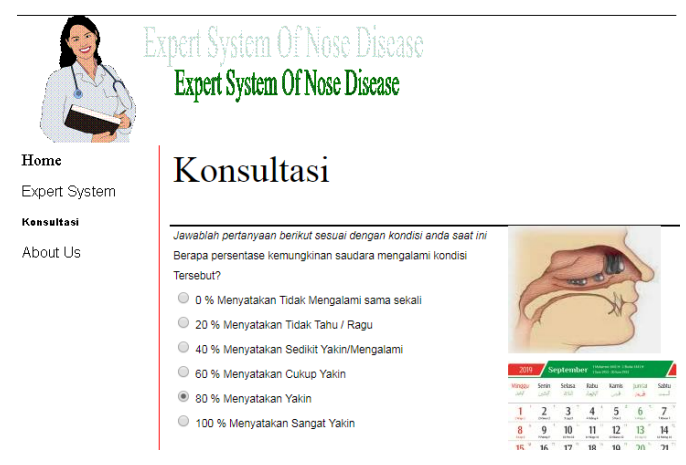

Figure 5.Consultation 
If the user answers NO then the system will continue to the next question until a conclusion or conclusion is reached. After determining the consultation by giving a percentage that is experienced then the system will continue the question to bring up the following conclusions:

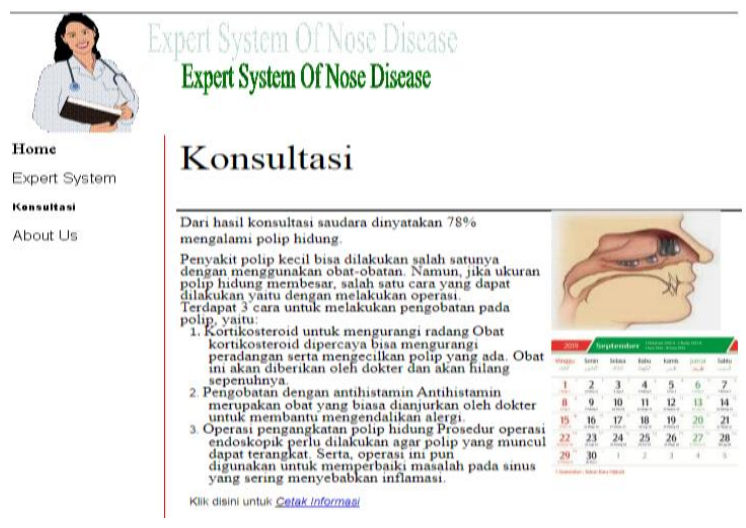

Figure 6.Decision Tree

Conclusion results from the system can be used in softcopy or even hardcopy by clicking on links in the system.

\section{CONCLUSION}

Based on the analysis and trial results of the system, the following conclusions are obtained:

1. There are several factors that can determine nose disease. The influencing factors are obtained from several choices given by the system, so that an expert system plan will be produced to determine whether a patient has nose disease or not.

2. Expert system that is designed to be able to analyze and provide an overview of the causes of nose disease.

3. This expert system is able to identify and provide solutions to the community and make it easier for experts to identify nose disease in the community.

4. Reasoning is done using the Hybrid method in order to provide accurate information of nose disease based on symptoms experienced by the patient.

5. The output of this system is in the form of information to help patients with nose disease or treatment for these sufferers in the initial stages which are seen by using a system in the form of softcopy or hardcopy.

\section{REFERENCES}

[1] Rismawan, T., \&Hartati, S. (2012). Case-Based Reasoning untukDiagnosaPenyakit THT (TelingaHidungdanTenggorokan). IJCCS (Indonesian Journal of Computing and Cybernetics Systems), 6(2).

[2] Tumbol, A. R., Tumbel, R. E. C., \&Palandeng, O. I. (2015). SurveiKesehatanHidungPadaMasyarakatPesisirPantaiBahu. e-CliniC, 3(1). 
[3] Sihotang,

$\mathrm{H}$.

T.

(2018).

Sistempakaruntukmendiagnosapenyakitpadatanamanjagungdenganmetodebayes. Journ al OfInformaticPelita Nusantara, 3(1).

[4] Rompis, N. N., Pelealu, O. C., \&Palandeng, O. I. (2018). KesehatanHidungpadaLansia di BalaiPelayananSosialLanjutUsiaTerlantarSenjaCerah Manado. e-CliniC, 6(2).

[5] Yenila, F., \&Wiyandra, Y. (2018). EXPERT SYSTEM PELANGGARAN KENDARAAN BERMOTOR DI INDONESIA DENGAN METODA FORWARDCHAINING. TEKNOLOGI, 6(2).

[6] Setyaputri, K. E., Fadlil, A., \&Sunardi, S. (2018). AnalisisMetode Certainty Factor padaSistemPakarDiagnosaPenyakit THT. JurnalTeknikElektro, 10(1), 30-35.

[7] Pourghasemi, H. R., Pradhan, B., Gokceoglu, C., Mohammadi, M., \&Moradi, H. R. (2013). Application of weights-of-evidence and certainty factor models and their comparison in landslide susceptibility mapping at Haraz watershed, Iran. Arabian Journal of Geosciences, 6(7), 2351-2365.

[8] Fallon, J., Plummeridge, M., Daly, R., \& Medford, A. (2018). Linear probe 19-gauge endobronchial ultrasound diagnosis of a benign chondroidhamartoma. Monaldi Archives for Chest Disease, 88(1).

[9] Abu-Nasser, B. S., \& Abu-Naser, S. S. (2018). Cognitive System for Helping Farmers in Diagnosing Watermelon Diseases. International Journal of Academic Information Systems Research (IJAISR), 2(7), 1-7.

[10]Harahap, N. I. K., Siregar, S. M., \&Nasution, M. E. S. (2018). PROFIL KUMAN PADA SEKRET HIDUNG PENDERITA RINOSINUSITIS KRONIS DI RUMAH SAKIT HAJI MEDAN. JURNAL IBNU SINA BIOMEDIKA, 2(1), 57-64. 